\title{
Path for the Effectiveness of the Ability of Democratic Parties in Colleges and Universities to Participate in Political Affairs in New Era
}

\author{
Dongdong Weng ${ }^{1}$, Xiaofang Wang ${ }^{2,}$, Yuxia Zhang ${ }^{3}$ \\ ${ }^{1}$ Quanzhou Normal University, Fujian, Quanzhou, China \\ ${ }^{2}$ Liming Vocational University, Fujian, Quanzhou, China \\ ${ }^{3}$ Quanzhou Normal University, Fujian, Quanzhou, China \\ *Corresponding author: Xiaofang Wang Email: weng2891985@163.com
}

Keywords: new era; democratic parties; colleges and universities; political affairs

\begin{abstract}
The research on the participation of democratic parties in colleges and universities has always been the key point in the study of the party's issues. Based on the introduction of the democratic parties in the new era, this paper analyzes the irreplaceable importance of the democratic parties in political parties, makes a theoretical perspective on the problems of democratic parties in the political parties in the process of participating in the political affairs of colleges and universities, and puts forward the corresponding measures, and a new viewpoint for the democratic parties' participation in political affairs in colleges and universities.
\end{abstract}

\section{Introduction}

In studying this subject, found that most colleges to study the important function of the democratic parties participate in actual construction and development are ignored, most of the literature on how to effectively improve the democratic parties participate in less actual operational strategy, viewpoint and method mostly convergence, lack of innovation. So, the idea of how to make an effective path in the context of a new age, and to make the point that it's not old, that it's innovative is the challenge of this project. At the central united front conference, general secretary $\mathrm{Xi}$ Jinping stressed that the work of the united front is an important work of the communist party of China in any historical environment. In the new era, we must master the methods, stick to the principles and do a good job on the united front in accordance with the law of united front.

\section{The Significance of the Study on the Ability of Democratic Parties to Participate in and Discuss Politics in Colleges and Universities}

Universities outside the party of the democratic parties is a representative of the colonies, strengthen the ability of the democratic parties participate in colleges and universities better able to select the outstanding person, so as to contribute to the construction of democratic politics in China.

China has always carried out the strategy of rejuvenating the country through science and education and strengthening the country with talents. Education has always been a priority, so the development of colleges and universities is an important part of this strategy. The 21st century is an era full of challenges. With the rise of the Internet, a great change has taken place in the market economy. This not only needs the party staff's hard work, also need the intellectuals play their role of democratic parties, arouse the enthusiasm of the democratic parties, let them actively participate in school construction, enhance their autonomy and creativity. In organizational management and decision-making increasingly motors, specialization of modern society, members of democratic parties in colleges and universities based on their own expertise and academic attainments of media and various platforms through different ways and perform the obligation to participate, they according to legal procedures and relevant requirements, devoted to the scientific research and teaching and school development and construction of school development and social progress strong support system. It can be seen that strengthening the construction of democratic parties in 
colleges and universities can improve the sense of responsibility and mission of party members, which is an essential condition for building a harmonious and progressive society.

\section{Problems Existing in the Participation and Discussion of Democratic Parties in Politics in Colleges and Universities}

As a member of the democratic parties of colleges and universities, he should have a strong sense of participating in politics and political mission, but he always ignored himself as a member of the democratic parties of colleges and universities due to various factors and lacked awareness of political participation. These negative factors led to the failure of the party's work function to be well reflected. For example, many members of the democratic parties as part of their job, the most of his life on the scientific research and teaching in colleges and universities, in order to obtain his satisfaction, physical and honor for the school major policies of the party construction and the national don't pester, familiar with the work and the important measures on a party is not, less contact with the outside world, neglected the cultivation participate in political consciousness, democratic supervision, and also for the usual lack of political literacy education and the lack of political experience, lead to political awareness is relatively lacking. Not perfect the democratic parties participate in running mechanism in colleges and universities work target is not clear, can cause organization way of working is not standard, party members blind passive don't know where to start, the lack of clear rules and regulations and detailed implementation rules. At present, the democratic parties in colleges and universities personnel selection system is relatively loose caused the various democratic parties among the members of the political quality of the good and bad are intermingled, and this kind of strewn at random will further affect the efficiency of the democratic parties participate in process in colleges and universities, and second, the democratic parties in colleges and universities is not a relatively complete mechanism for new members to join the further to understand the party constitution rewards and punishments, etc., which will cause each college members to join their understanding of the democratic parties, the party is difficult to manage. Again, the democratic parties in colleges and universities set up a complete rarely communication to promote the exchange of party members, at the same time, the democratic parties in colleges and universities lack of perfect management, this to some extent, leading to many of the activities and work to develop smoothly, participate in the road is impossible, this is also related to the democratic parties need to reflect on the problem.

\section{Solutions for the Problem of the Democratic Parties Participating in Politics in Colleges and Universities}

First of all, to participate in channels, universities should actively contact with the parties, developing a corresponding concept of democratic parties in colleges and universities often propaganda, regularly held the democratic parties participate in seminars, combined with the major policies of the state, or work around the current school management planning and development, actively make recommendations, and put forward their constructive and innovative ideas and proposals. Members of democratic parties should also seize this opportunity to enhance their ability to participate in politics and to actively integrate themselves into the political atmosphere. Second, it is best to by all parties to cooperate, establish and perfect the democratic consultation channels and platform, make party members walked out of the political participation is a leadership role needs to be done and what's not has the erroneous zone. At the same time, the party organs should ensure that the members of democratic parties in the political participation of university knowledge channel unobstructed, reduction in rank and position the finest gap caused by information asymmetry problem, for party members to keep high enthusiasm to understand information related to the political. In addition, also want to do a good job of coordination of the united front department, make the democratic parties in colleges and universities can be organized in a planned way to collect public opinion, further study of selected topic, the information flow.

Democratic parties should constantly strengthen their own development, study the history and 
constitution of their respective parties, and carry forward and carry forward the fine traditions of democratic parties. We should unify our thinking, change our ideas, strengthen our awareness of participating in politics and discussing politics, and enhance our sense of honor, responsibility and mission as participating parties. In terms of the party member troop construction, the ruling party there is a lot of experience to the democratic parties, improve the cadre talent development planning, implement step by step training to ensure quality of cadres, widen the channel of the cadre training, learning campaign and competitive election system, introduced the ruling party, the reserve cadre selection and appointment of realize the institutionalization, standardization, develop a comprehensive and detailed operation rules. As members of the democratic parties in colleges and universities in the new era, efforts should be made to improve its ability to participate in, so that we can better help the ruling science ruling, improve the efficiency of the political party in power and better protect the livelihood of the people. Therefore, it is necessary for members of democratic parties to improve their ability to participate in and discuss politics. Democracy party members in colleges and universities in continuously consolidate their own academic knowledge at the same time, for current events to have self judgment and understanding, in cultivating their own on the basis of correct political outlook should have its own unique insights, unique insights from the steady accumulation of experience. Entered the new era, profound changes have taken place in the structure of the Democratic Party members in colleges and universities, there have been some new situations and new problems: on the one hand, all the party members constitute more and more diversified, extended from traditional key characteristic fields to many areas, look from the ideological concept, value orientation more hasten is multivariate, from single to multiple practical ideals change; On the other hand, a group of high-level intellectuals and academic leaders have been gradually absorbed by democratic parties and assumed leadership positions. Their growth experience and political participation are obviously different.

In order to reflect the new requirement of democratic parties in colleges and universities to better perform their functions, it is necessary to make efforts and take effective measures to improve their ability to participate in and discuss politics. To improve the ability of democratic parties to participate in and discuss politics, we must adhere to the characteristic orientation of democratic parties and promote the development of distinctive features. Select the leading party figures and play the role of model demonstration; Carry out accurate training to effectively promote capacity improvement; Correctly handle the relationship between party affairs and business, and realize the construction of dual posts. We will give full play to the role of the party committee and establish a normal working mechanism.

\section{Conclusions}

University ability of the democratic parties participate in effectiveness promotion target of the research is mainly based on the new era background, on the basis of the existing theory research are summarized and put forward some innovative ideas, and the democratic parties participate in capacity effectiveness for colleges and universities put forward effective improvement of specific operational measures and implementation measures. Colleges and universities should expand channels, encourage members of democratic parties to actively participate in politics and discussion, and offer Suggestions and Suggestions for the development and construction of schools and the building of a moderately prosperous society in all respects. Members of democratic parties should constantly strengthen theoretical study and social practice, improve their own political and ideological level and operational capability, and give full play to their functions and rights of participating in and discussing politics and exercising democratic supervision. As democracy party members in colleges and universities participate in important and key role prompted us to continue thinking innovation, strive to build a more suitable to participate in the democratic parties in colleges and universities to improve and growth ability, to facilitate better service to college and social effective mechanism. 


\section{Acknowledgement}

2018 Fujian Province Young and Middle-aged Teacher Education Research Project "I Offer Good Strategies for Building New Fujian" (United Front Work Project) (Key Funding Project) (JAS180019).

Quanzhou Teachers College Student Innovation and Entrepreneurship Training Program Project Funding (Project No.: 201810399120).

\section{References}

[1] Cui Beijun.Strengthening the Capacity Building of Democratic Parties' Participation in Politics and Politics_-Taking Bengbu City of Anhui Province as an Example[J],Journal of Shaanxi Institute of Socialism2014,01:37-42.

[2] Jian ping.Comply with the Requirements of the Development of the Times, Improve the Ability of Participating in Politics and Discussing Politics_-Thinking about the Role of Democratic Parties in Participating in Politics and Deliberation[J],Inner Mongolia Theory of United Front,2010,No.15504:10-12.

[3] Zhong Jun.On the improvement of the working mechanism of the democratic parties participating in the administration of state affairs [J].Journal of Chongqing Institute of Socialism,2012,v.15:27-29.

[4] Chang Yiqing.On the Role of Democratic Parties in the Construction and Development of Colleges and Universities [J]. Journal of South-Central University for Nationalities, 2014, 01:37-42.

[5] Gao Huihong. Reflections on the Role of Democratic Parties in Legislative Consultation [J]. Advance Forum, 2015(4):31-32.

[6] Yu Xiaogang, Jiang Xianqi, Chen Guolin. On the Significance and Ways of Building a Leading Group for Unity and Cooperation [J]. Advance Forum, 2015(4):41-22. 